\title{
Adaptability of lettuce cultivars to planting in no-tillage on straw of Urochloa ruziziensis
}

\author{
Andréia Cristina Silva Hirata(1), Edson Kiyoharu Hirata(2) and João Augusto Rizzo Camara(2)
}

(1)Agência Paulista de Tecnologia dos Agronegócios, Polo Regional da Alta Sorocabana, Caixa Postal 298, CEP 19015-970 Presidente Prudente, SP, Brazil. E-mail: andreiacs@apta.sp.gov.br (2)Universidade do Oeste Paulista, Rodovia Raposo Tavares, Km 572, CEP 19067-175 Presidente Prudente, SP, Brazil. E-mail: hirataedson@hotmail.com, guto_k3@hotmail.com

\begin{abstract}
The objective of this work was to evaluate the adaptability of different lettuce (Lactuca sativa) cultivars grown in no-tillage on straw of ruzi grass (Urochloa ruziziensis), as well as its effects on soil temperature and weed control, in successive cultivations in the summer. The treatments were carried out in a randomized complete block design, with four replicates, in a split-plot arrangement $(2 \times 4)$, in which soil management (no-tillage on ruzi grass and convention tillage) was the main plot, and the different crisphead lettuce cultivars (Amanda, Solaris, Vanda, and Vera), the subplots. No difference was observed between cultivars for soil management. No-tillage reduced the soil temperature by up to $3.7^{\circ} \mathrm{C}$ and weed density by 3.7 times, in comparison with conventional tillage. Ruzi grass promoted a greater bed conservation. In comparison to with conventional tillage, the no-tillage management of lettuce cultivated on ruzi grass straw resulted in a lower yield in the first crop due to excess straw; in a similar yield in the second crop; and in a greater yield in the third crop. Lettuce cultivated on ruzi grass straw in no-tillage management results in a greater sustainability, in comparison with conventional tillage, in three successive plantings.
\end{abstract}

Index terms: Brachiaria, Lactuca sativa, soil conservation, soil temperature, vegetable crops, weeds.

\section{Adaptabilidade de cultivares de alface ao plantio direto sobre palhada de Urochloa ruziziensis}

Resumo - O objetivo deste trabalho foi avaliar a adaptabilidade de cultivares de alface (Lactuca sativa) ao plantio direto sobre palhada de capim-congo (Urochloa ruziziensis), assim como seu efeito sobre a temperatura do solo e o controle de plantas daninhas, em cultivos sucessivos no verão. Os tratamentos foram dispostos no delineamento experimental de blocos ao acaso, com quatro repetições, em arranjo de parcelas subdivididas (2x4), em que os manejos do solo (plantio direto sobre capim-congo e plantio convencional) constituíram a parcela principal, e as diferentes cultivares de alface tipo crespa (Amanda, Solaris, Vanda e Vera), as subparcelas. As cultivares não diferiram entre si quanto ao manejo do solo. O plantio direto reduziu a temperatura do solo em até $3,7^{\circ} \mathrm{C}$, e a densidade de plantas daninhas em 3,7 vezes, em comparação ao plantio convencional. O capim-congo promoveu a maior conservação dos canteiros. Em comparação ao plantio convencional, o plantio direto de alface sobre palhada de capim-congo resultou em produtividade menor no primeiro cultivo, em razão do excesso de palha; em produtividade semelhante, no segundo cultivo; e produtividade superior, no terceiro cultivo. O cultivo de alface em plantio direto sobre palhada de capimcongo resulta em maior sustentabilidade, em comparação ao plantio convencional, ao longo de três cultivos sucessivos.

Termos para indexação: Brachiaria, Lactuca sativa, conservação do solo, temperatura do solo, hortaliças, plantas daninhas.

\section{Introduction}

Great improvements have been observed in notillage systems for large-scale crops in Brazil; however, intensive soil disturbance predominates in vegetable crops (Oliveira et al., 2006). Concerns over soil degradation have encouraged some countries to decrease mechanical soil tillage operations (Price \& Norsworthy, 2013; Pieper et al., 2015). Due to the evidence of excess soil tillage, the search for alternative soil management systems has been intensified because of their potential for increasing soil-water retention (Fontes et al., 2007). 
The growth of vegetable crops under no-tillage on straw of cover crops has been stimulated, aiming at the sustainability of natural resources in vegetable crop production. Researches have been implemented to increase the sustainability of the production of vegetable crops, such as lettuce (Hirata et al., 2014), green onion (Araújo Neto et al., 2010), and coriander (Tavella et al., 2010), among others, in no-tillage systems. Some studies have shown that different cultivars of a vegetable crop can differ for their adaptability to the same production system (Meagy et al., 2013; Resende et al., 2016), and that it is important to assess the compatibility of cultivars to a reduced soil tillage.

Another important aspect in vegetable crop production is the difficulty of production in summer conditions. Despite the advances of genetic breeding for tropically adapted lettuce by the development and release of cultivars more adapted to tropical conditions (Sala \& Costa, 2012), lettuce grown in the summer period shows a decreased yield and early bolting (Resende et al., 2007; Ferreira et al., 2009; Lafta et al., 2017); therefore, alternative production systems are required for this planting period.

Because of the high-carbon/nitrogen ratio in their composition, grasses from the Urochloa genus are an option for straw production in no-tillage systems (Nepomuceno et al., 2012). Ruzi grass [Urochloa ruziziensis (Syn. Brachiaria ruziziensis)] also produces an excellent suppression effect for weed control (Silva Hirata et al., 2009). In general, a previous planting of grass suppresses populations of Rhizoctonia spp. and Fusarium spp. in the soil (Toledo-Souza et al., 2008). However, further studies are required to identify appropriate cover crops and tillage systems, to increase sustainability in other agricultural settings such as vegetable crops (Price \& Norsworthy, 2013).

The objective of this work was to evaluate the adaptability of lettuce cultivars grown in no-tillage management on straw of ruzi grass, as well as its effects on soil temperature and weed control in successive crops in the summer.

\section{Materials and Methods}

The experiment was carried out in the vegetable production sector of Polo Regional da Alta Sorocabana, from Agência Paulista de Tecnologia dos Agronegócios, in the municipality of Presidente Prudente, in the state of São Paulo, Brazil (22 $07^{\prime} 21^{\prime \prime S}, 51^{\circ} 23^{\prime} 17^{\prime \prime} \mathrm{W}$, at $460 \mathrm{~m}$ altitude), from September 2015 to April 2016.

According to the classification of Köppen-Geiger, the predominant climate in the region is Aw, characterized by tropical rainy summers with dry winters. The coldest month shows an average temperature higher than $18^{\circ} \mathrm{C}$, and the driest month shows precipitation lower than $60 \mathrm{~mm}$ (Ciiagro, 2016). The rainfall data during the experiment, as well as the maximum, mean, and minimum temperatures are presented in Figure 1.

The soil in the experimental area is classified as an Argissolo Vermelho-Amarelo distrófico arênico (Arenic Hapludult). Soil chemical characteristics in the arable layer $(0-20 \mathrm{~cm})$ were determined according to the methods of Raij et al. (2001), as follows: $\mathrm{pH}\left(\mathrm{CaCl}_{2}\right)$ 6.0 ; soil organic matter, $14 \mathrm{~g} \mathrm{dm}^{-3}$; base saturation, 86\%; Ca, 45 mmol $_{\mathrm{c}} \mathrm{dm}^{-3} ; \mathrm{Mg}, 18 \mathrm{mmol}_{\mathrm{c}} \mathrm{dm}^{-3} ; \mathrm{H}+\mathrm{Al}$, $11 \mathrm{mmol}_{\mathrm{c}} \mathrm{dm}^{-3} ; \mathrm{P}_{\text {resin }}, 91 \mathrm{mg} \mathrm{dm}^{-3} ; \mathrm{K}, 2.5 \mathrm{mg} \mathrm{dm}^{-3} ; \mathrm{Zn}$, $2.8 \mathrm{mg} \mathrm{dm}^{-3}$; Fe, $17 \mathrm{mg} \mathrm{dm}^{-3}$; Mn, $9.9 \mathrm{mg} \mathrm{dm}^{-3} ; \mathrm{Cu}, 2.3$ $\mathrm{mg} \mathrm{dm} \mathrm{m}^{-3}$; and $\mathrm{B}, 0.17 \mathrm{mg} \mathrm{dm}^{-3}$. The soil has a sandy loam texture, containing $833 \mathrm{~g} \mathrm{~kg}^{-1}$ sand, $103 \mathrm{~g} \mathrm{~kg}^{-1}$ silt, and $64 \mathrm{~g} \mathrm{~kg}^{-1}$ clay.

The experimental design was a randomized complete block, with four replicates, in a split-plot arrangement. In the plots, the treatments were soil tillage (no-tillage on ruzi grass straw and conventional tillage), and, in the subplots, four lettuce cultivars (Amanda, Solaris, Vanda, and Vera).

The soil in the experimental area was prepared using a disc harrow and a leveling disc harrow. For raised beds of $1.2 \mathrm{~m}$ width and $0.30 \mathrm{~m}$ height, a rotary tiller was used. Ruzi grass was established by broadcasting seed in the plots on September 28, 2015, with $17 \mathrm{~g} \mathrm{~m}^{-2}$ of pure encrusted seed.

The chemical desiccation of ruzi grass was performed using glyphosate $\left(1,440.0 \mathrm{~g}\right.$ a.i. ha $\left.{ }^{-1}\right)$, on December 12, 2015, when forage was $65-70 \mathrm{~cm}$ high. Ruzi grass straw used in lettuce planting was at $7 \mathrm{Mg}$ $\mathrm{ha}^{-1}$. The beds of conventional treatment plots were raised on December 18, 2015.

Planting and topdressing fertilization were conducted according to the recommendations of Trani et al. (2014). Phosphorus fertilization was performed using thermophosphate, incorporated into the soil with ruzi grass sowing (no-tillage treatments), or when beds were raised (conventional tillage treatments). Nitrogen 
and potassium fertilizations were applied through fertigation, using half the recommended dose.

The lettuce seedlings (crisphead group) were produced in polypropylene trays with capacity for 288 seedlings. Lettuce seedlings were transplanted at 21 days after sowing, at $0.30 \times 0.30 \mathrm{~m}$ spacing. The plantings were performed on December 26, 2015, February 6, 2016, and March 3, 2016. After each cultivation, the original plots were maintained, and glufosinate-ammonium was applied to dry the weeds. Water was supplied using a drip system, with three lines of drip-irrigation tubing arranged per plot. Drip holes were spaced at $0.30 \mathrm{~m}$ intervals.

The total plot area was $5.04 \mathrm{~m}^{2}-4.2 \mathrm{~m}$ long and $1.2 \mathrm{~m}$ wide. Four rows of lettuce were planted in each plot, resulting in 56 plants per plot. The two central rows, that is, excluding the border rows, constituted the useful plot size. The plots were kept weed-free by hand hoeing.

Soil temperature was evaluated using type-K thermocouple calibration sensors, with rigid stainless steel rods of $10 \mathrm{~mm}$ diameter, coupled to digital thermometers. Temperature sensors were installed at $2.5 \mathrm{~cm}$ soil depth, in the central area of the plots. The temperatures were evaluated at 8:00 h and at 14:00 h. Evaluations were performed by inserting thermometers in all treatments of each block simultaneously. The soil temperature was accomplished in all lettuce crops, just before the lettuce canopy closed.

Weed samples were collected before hand-hoeing (15 days after planting) in each crop. Samples were collected by throwing a $0.30 \mathrm{x} 0.30 \mathrm{~m}$ square quadrat at random, twice per plot. Weeds within the square quadrat were identified, counted, and dried in a forcedair oven at $65^{\circ} \mathrm{C}$, until a constant weight was obtained.

Chlorophyll index measurements were determined at harvest, using the Minolta SPAD-502 portable indirect chlorophyll meter (Minolta, 1989), in three lettuce growing seasons. Readings were taken from the ten fully expanded leaf, most recently developed per plot.

Ruzi grass straw was evaluated after each crop season, with samples collected by throwing a $0.30 \times 0.30 \mathrm{~m}$ square quadrat at random, twice per plot.

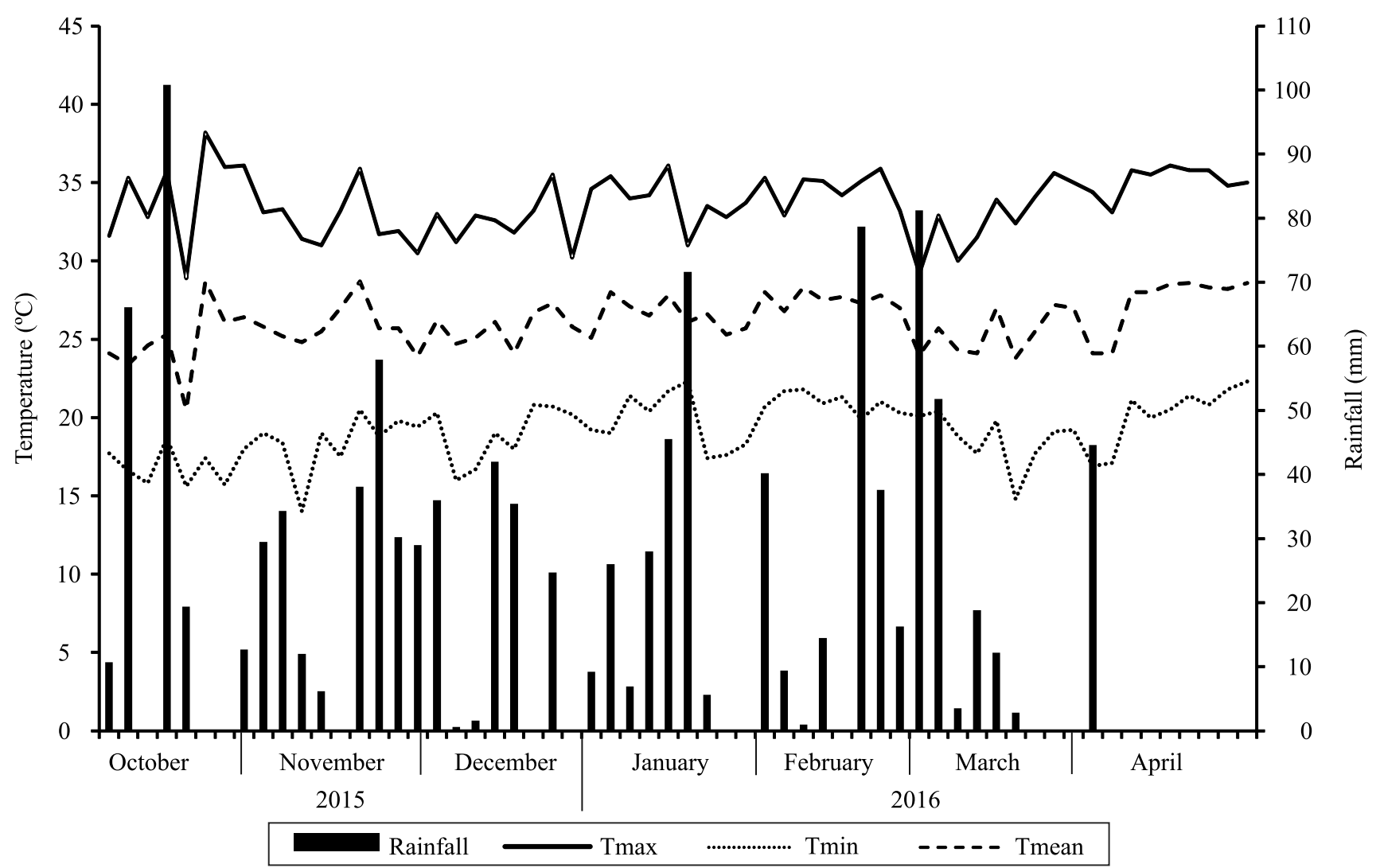

Figure 1. Weather data for rainfall, and maximum, mean, and minimum air temperatures, during ruzi grass (Urochloa ruziziensis) and lettuce (Lactuca sativa) cultivations, from September 28, 2015, to April 24, 2016. Source: Ciagro (2016). 
The collected straw was dried in a forced-air oven at $65^{\circ} \mathrm{C}$, until a constant weight was obtained. After the third crops, the bed height was evaluated.

At harvest, fresh weight was determined by cutting the plants close to the soil, just below the basal leaves. Senescent or diseased leaves were discarded, and lettuce yield (fresh weight) was evaluated. Head diameter, stem diameter, and number of leaves were measured in five plants from the useful plot area.

Data were subjected to the analysis of variance, at $5 \%$ probability, and qualitative means were evaluated by the Tukey's test, using the Assistat software (Silva, 2008). The quantitative means were evaluated by regression analyses.

\section{Results and Discussion}

The lettuce cultivar plots showed similar soil temperatures, irrespectively of soil management, which indicates that soil cover by canopy of cultivars was similar (Table 1). According to Oliveira et al. (2005), the temperature close to the soil surface is directly affected by its cover, which tends to intercept the sun rays before they strike the surface, resulting in a specific microclimate under the straw.

The no-tillage treatment showed its highest temperature at 8:00 h, which indicates a lower-heat loss during the night. Blanco-Canqui et al. (2015) explain that cover crops control soil temperature by the increase of minimum temperature and the decrease of maximum

Table 1. Soil temperature at 8:00 A.M. and 2:00 P.M. time points (hour) in different lettuce (Lactuca sativa) cultivars transplanted in no-tillage on straw of ruzi grass (Urochloa ruziziensis) or in conventional tillage, in successive crops $^{(1)}$.

\begin{tabular}{|c|c|c|c|c|c|c|}
\hline \multirow[t]{3}{*}{ Cultivar } & \multicolumn{6}{|c|}{ Soil-temperature $\left({ }^{\circ} \mathrm{C}\right)$ at $2.5 \mathrm{~cm}$ depth } \\
\hline & \multicolumn{2}{|c|}{ Crop 1} & \multicolumn{2}{|c|}{ Crop 2} & \multicolumn{2}{|c|}{ Crop 3} \\
\hline & $8: 00$ & $2: 00$ & $8: 00$ & $2: 00$ & $8: 00$ & $2: 00$ \\
\hline Amanda & $21.2 \mathrm{a}$ & $29.5 \mathrm{a}$ & $22.9 \mathrm{a}$ & $29.0 \mathrm{a}$ & $22.2 \mathrm{a}$ & $26.9 \mathrm{a}$ \\
\hline Solaris & $21.4 \mathrm{a}$ & $30.1 \mathrm{a}$ & $22.7 \mathrm{a}$ & $29.5 \mathrm{a}$ & $22.1 \mathrm{a}$ & $26.7 \mathrm{a}$ \\
\hline Vanda & $21.3 \mathrm{a}$ & $29.7 \mathrm{a}$ & $22.9 \mathrm{a}$ & $29.0 \mathrm{a}$ & $21.9 \mathrm{a}$ & $27.5 \mathrm{a}$ \\
\hline Vera & $21.3 \mathrm{a}$ & $29.1 \mathrm{a}$ & $22.9 \mathrm{a}$ & $29.6 \mathrm{a}$ & $22.2 \mathrm{a}$ & $27.0 \mathrm{a}$ \\
\hline CV (\%) & 1.5 & 3.0 & 0.9 & 2.0 & 1.7 & 2.4 \\
\hline \multicolumn{7}{|l|}{ Tillage } \\
\hline No-tillage & $21.9 \mathrm{a}$ & $27.8 \mathrm{~b}$ & $22.9 \mathrm{a}$ & $29.0 \mathrm{a}$ & $22.2 \mathrm{a}$ & $26.8 \mathrm{a}$ \\
\hline Conventional & $20.7 \mathrm{~b}$ & $31.5 \mathrm{a}$ & $22.8 \mathrm{a}$ & $29.5 \mathrm{a}$ & $22.0 \mathrm{a}$ & $27.2 \mathrm{a}$ \\
\hline CV (\%) & 2.2 & 4.4 & 1.3 & 1.9 & 1.9 & 4.8 \\
\hline
\end{tabular}

${ }^{(1)}$ Means followed by equal letters, in the columns, do not differ by Tukey's test, at 5\% probability. temperature. At 2:00 P.M., a temperature reduction of $3.7^{\circ} \mathrm{C}$ was observed in no-tillage management plots, in comparison with the conventional tillage. Horton et al. (1996) reported that straw has a higher albedo and lower-thermal conductivity than bare soil, reducing the solar energy reaching the soil.

In the second and third crops, there was no difference for soil temperature among soil management practices. A high reduction of the amount of straw at the end of the second crop (Figure 2), maximized by rainfall in this period, explained these results. Blanco-Canqui et al. (2015) reported that the amount of biomass strawresidues can determine the magnitude at which temperature is affected by a cover crop.

The cultivars did not differ for weed suppression, which is an evidence of a similar architecture and growth rate among cultivars. Beckie et al. (2008) found that weed suppression was positively correlated with canola and mustard biomass accumulation. However, Colquhoun et al. (2009) reported no difference among potato cultivars regarding the reduction of weed biomass.

High-weed infestation levels were observed in the first crop (Table 2). In conventional tillage, weed density and dry mass were 3.7 and 3.3 times greater, respectively, in comparison with no-tillage on ruzi grass. There was no significant difference among treatments in the second crop; however, the total density was reduced in comparison with the first crop.

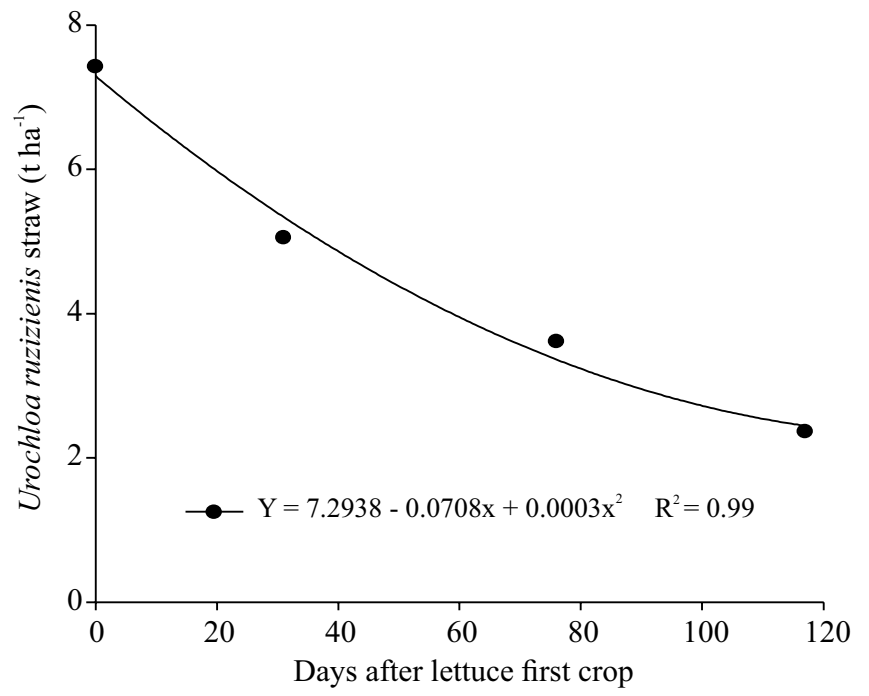

Figure 2. Decomposition of ruzi grass (Urochloa ruziziensis) straw over time in three lettuce (Lactuca sativa) cultivations.

Pesq. agropec. bras., Brasília, v.53, n.7, p.824-832, July 2018 DOI: 10.1590/S0100-204X2018000700006 
The conventional tillage resulted in higher values of weed density and total dry mass, in the third crop.

The reduction of weed density and dry mass in both management systems, observed in the second and third crops, occurred because even in the conventional tillage treatment the soil was not disturbed between the cultivations. Baskin \& Baskin (2006) reported that soil disturbance brings seed to the soil surface, which exposes them to light and encourages the germination of nondormant species. Silva Hirata et al. (2009) observed a high-weed control by ruzi grass in notillage tomato. According to Murphy et al. (2006), the reduction of soil tillage, in association with an adequate crop rotation, results in the decrease of weed density. Ruzi grass facilitated both functional soil cover and crop rotation.

The number of weed species was similar among the soil tillage types, with 18,13 , and 17 species surveyed in the first, second, and third crops, respectively (Table 3). Monocotyledons were predominant, particularly

Table 2. Dry matter and total density of weeds in the cultivation of different crisphead lettuce (Lactuca sativa) cultivars transplanted and managed in no-tillage, on straw of ruzi grass (Urochloa ruziziensis) or in conventional tillage, in successive crops $^{(1)}$.

\begin{tabular}{|c|c|c|c|c|c|c|}
\hline \multirow[t]{2}{*}{ Cultivar } & \multicolumn{3}{|c|}{ Total dry matter $\left(\mathrm{g} \mathrm{m}^{-2}\right)$} & \multicolumn{3}{|c|}{ Total density (plants $\mathrm{m}^{-2}$ ) } \\
\hline & Crop 1 & Crop 2 & Crop 3 & Crop 1 & Crop 2 & Crop 3 \\
\hline Amanda & $4.1 \mathrm{a}$ & $7.2 \mathrm{a}$ & $0.7 \mathrm{a}$ & $250.7 \mathrm{a}$ & $199.3 \mathrm{a}$ & $69.4 a$ \\
\hline Solaris & $3.1 \mathrm{a}$ & $5.9 \mathrm{a}$ & $0.5 \mathrm{a}$ & $209.0 \mathrm{a}$ & $170.1 \mathrm{a}$ & $44.4 \mathrm{a}$ \\
\hline Vanda & $5.6 \mathrm{a}$ & $8.4 \mathrm{a}$ & $0.8 \mathrm{a}$ & $404.2 \mathrm{a}$ & $141.0 \mathrm{a}$ & $75.7 \mathrm{a}$ \\
\hline Vera & $5.9 \mathrm{a}$ & $8.6 \mathrm{a}$ & $0.4 \mathrm{a}$ & $342.4 \mathrm{a}$ & $168.0 \mathrm{a}$ & $45.1 \mathrm{a}$ \\
\hline $\mathrm{CV}(\%)$ & 63.7 & 63.0 & 61.4 & 49.7 & 39.8 & 56.5 \\
\hline \multicolumn{7}{|l|}{ Tillage } \\
\hline No-tillage & $2.2 b$ & $4.4 \mathrm{a}$ & $0.2 b$ & $126.7 \mathrm{~b}$ & $154.2 \mathrm{a}$ & $29.2 b$ \\
\hline Conventional & $7.2 \mathrm{a}$ & $10.6 \mathrm{a}$ & $1.0 \mathrm{a}$ & $476.4 \mathrm{a}$ & $185.1 \mathrm{a}$ & $88.2 \mathrm{a}$ \\
\hline $\mathrm{CV}(\%)$ & 60.2 & 73.7 & 58.1 & 46.5 & 25.4 & 59.3 \\
\hline
\end{tabular}

${ }^{(1)}$ Means followed by equal letters, in the columns, do not differ by Tukey's test, at 5\% probability.

Table 3. Weed species sampled in an experimental area, in the cultivation of different crisphead lettuce (Lactuca sativa) cultivars transplanted and managed in no-tillage (NT), on straw of ruzi grass (Urochloa ruziziensis) or in conventional tillage (CT), in successive crops.

\begin{tabular}{|c|c|c|c|c|c|c|}
\hline \multirow[t]{2}{*}{ Species } & \multicolumn{2}{|c|}{ Crop 1} & \multicolumn{2}{|c|}{ Crop 2} & \multicolumn{2}{|c|}{ Crop 3} \\
\hline & NT & $\mathrm{CT}$ & NT & $\mathrm{CT}$ & NT & CT \\
\hline & \multicolumn{6}{|c|}{ plants $\mathrm{m}^{-2}$} \\
\hline Digitaria horizontalis & 66.00 & 237.85 & 71.20 & 42.70 & 9.00 & 20.15 \\
\hline Eleusine indica & 6.63 & 82.30 & 30.58 & 88.53 & 13.55 & 47.93 \\
\hline Cyperus spp. & 34.73 & 68.05 & 18.75 & 17.00 & 1.75 & 7.30 \\
\hline Commelina benghalensis & 8.33 & 21.88 & 19.10 & 28.83 & 3.50 & 6.60 \\
\hline Chenopodium album & 0.35 & 40.98 & 2.78 & 0.70 & 0.35 & 3.48 \\
\hline Portulaca oleracea & 1.40 & 7.98 & 7.65 & 2.45 & 1.05 & 1.75 \\
\hline Amaranthus spp. & 2.45 & 5.23 & 0.70 & 1.05 & 0.00 & 1.05 \\
\hline Richardia brasiliensis & 1.40 & 3.15 & 0.70 & 0.70 & 0.00 & 0.00 \\
\hline Indigofera hirsuta & 0.00 & 3.15 & 0.00 & 2.45 & 0.00 & 0.00 \\
\hline Sida spp. & 2.10 & 2.80 & 0.00 & 0.35 & 0.00 & 0.00 \\
\hline Chamaesyce hirta & 0.35 & 0.00 & 2.10 & 0.00 & 0.00 & 0.00 \\
\hline Brachiaria decumbens & 0.70 & 1.40 & 0.00 & 0.00 & 0.00 & 0.00 \\
\hline Euphorbia heterophylla & 1.40 & 0.00 & 0.00 & 0.00 & 0.00 & 0.00 \\
\hline Panicum maximum & 0.00 & 0.35 & 0.70 & 0.00 & 0.00 & 0.00 \\
\hline Bidens pilosa & 0.00 & 1.05 & 0.00 & 0.00 & 0.00 & 0.00 \\
\hline Portulaca pilosa & 0.70 & 0.00 & 0.00 & 0.00 & 0.00 & 0.00 \\
\hline Acanthospermum hispidum & 0.00 & 0.00 & 0.00 & 0.35 & 0.00 & 0.00 \\
\hline Cenchrus echinatus & 0.35 & 0.00 & 0.00 & 0.00 & 0.00 & 0.00 \\
\hline Solanum americanum & 0.00 & 0.35 & 0.00 & 0.00 & 0.00 & 0.00 \\
\hline Total & 126.88 & 476.50 & 154.25 & 185.10 & 29.20 & 88.25 \\
\hline
\end{tabular}


Digitaria horizontalis and Eleusine indica. A high density of Cyperus spp., Commelina benghalensis, and Chenopodium album was also recorded. The no-tillage management achieved a high-weed suppression of $E$. indica (6.63 plants $\mathrm{m}^{-2}$ in no-tillage, and 82.3 plants $\mathrm{m}^{-2}$ in conventional tillage) and C. album (0.35 plants $\mathrm{m}^{-2}$ in no-tillage, and 40.98 plants $\mathrm{m}^{-2}$ in conventional tillage), in the first crop. These findings corroborate the results found by Peachey et al. (2004), who reported a reduced emergence of Solanum sarrachoides from 77 to $99 \%$, and Amaranthus powellii from 50 to $87 \%$, in a no-tillage system, in comparison with conventional tillage.

Pannacci et al. (2017) reported the importance of no-chemical weed management strategies in minor crops because of the low availability, or absence, of herbicides for these vegetable crops. Thus, considering the difficulty of finding selective herbicides for broadleaf weed control in lettuce, this crop system offers the potential for high-labor savings for hand hoeing.

As to crop yield potential, a higher-lettuce fresh weight was recorded for conventional tillage than for no-tillage, in the first crop (Table 4). In the second crop, the lettuce production was similar among tillage managements. In the third crop, however, the notillage system was superior to conventional tillage. Jokela \& Nair (2016) reported a higher-broccoli yield in the conventional tillage than in no-tillage, on rye and hairy vetch in the first crop, with equal yields in the second crop.

The lower-lettuce fresh weight recorded in the first crop can be attributed to lettuce planted 14 days after the chemical desiccation of ruzi grass that resulted in more straw on the soil surface. The process of ruzi grass root and shoot degradation limited the growth of lettuce, a vegetable that is adapted to soil with more intense tillage and without mechanical resistance. Despite this fact, planting after a short time following desiccation resulted in a high yield for this first year period (302 g per plant). Constantin et al. (2007) reported etiolation of corn that was sown in a period close to desiccation time, in an area that had high-cover crop residues. According to the authors, the greater energetic losses in the initial crop cycle resulted in a reduction of crop development, as the effectiveness of desiccation, or "lodging" of the cover crop, can affect future crop development.
Yield losses have been verified in annual crops, when their sowings were performed soon after grass desiccation (Argenta et al., 2001; Corrêa et al., 2008). Grasses provide the advantage of maintenance cover on the soil surface for a longer period because of their high-carbon/nitrogen ratio. However, during the initial decomposition, there is a tendency of nutrient immobilization, as their sources in the cover crop residues are not sufficient for the microbial decomposition community, mainly nitrogen, which results in the reduction of some nutrients for the crops (Teixeira et al., 2009). Despite the higher-straw amount

Table 4. Yield and yield components of different crisphead lettuce (Lactuca sativa) cultivars transplanted and managed in no-tillage, on straw of ruzi grass (Urochloa ruziziensis) or in conventional tillage, in sucessive crops.

\begin{tabular}{|c|c|c|c|c|}
\hline \multirow{2}{*}{ Cultivar } & \multicolumn{4}{|c|}{ Yield components } \\
\hline & HD & NL & SD & SWF \\
\hline & \multicolumn{4}{|c|}{ Crop 1} \\
\hline Amanda & $35.8 \mathrm{a}$ & $21.7 \mathrm{ab}$ & $2.5 \mathrm{a}$ & $340.1 \mathrm{a}$ \\
\hline Solaris & $35.3 \mathrm{a}$ & $19.9 \mathrm{~b}$ & $2.4 \mathrm{a}$ & $303.7 \mathrm{a}$ \\
\hline Vanda & $34.5 \mathrm{a}$ & $23.1 \mathrm{a}$ & $2.6 \mathrm{a}$ & $364.5 \mathrm{a}$ \\
\hline Vera & $35.2 \mathrm{a}$ & $21.5 \mathrm{ab}$ & $2.5 \mathrm{a}$ & $341.5 \mathrm{a}$ \\
\hline CV (\%) & 3.7 & 6.9 & 4.5 & 15.8 \\
\hline \multicolumn{5}{|l|}{ Tillage } \\
\hline No-tillage & $34.6 \mathrm{a}$ & $20.5 \mathrm{a}$ & $2.4 \mathrm{a}$ & $302.0 \mathrm{~b}$ \\
\hline Conventional & $35.8 \mathrm{a}$ & $22.6 \mathrm{a}$ & $2.6 \mathrm{a}$ & $372.9 \mathrm{a}$ \\
\hline \multirow[t]{2}{*}{ CV (\%) } & 7.2 & 9.9 & 8.2 & 13.4 \\
\hline & \multicolumn{4}{|c|}{ Crop 2} \\
\hline Amanda & $35.8 \mathrm{a}$ & $20.7 b$ & $2.4 \mathrm{~b}$ & $258.0 \mathrm{ab}$ \\
\hline Solaris & $35.1 \mathrm{a}$ & $21.3 b$ & $2.4 \mathrm{~b}$ & $248.0 \mathrm{~b}$ \\
\hline Vanda & $36.1 \mathrm{a}$ & $25.7 \mathrm{a}$ & $2.7 \mathrm{a}$ & $291.5 \mathrm{a}$ \\
\hline Vera & $35.2 \mathrm{a}$ & $21.4 \mathrm{~b}$ & $2.4 \mathrm{~b}$ & $259.0 \mathrm{ab}$ \\
\hline CV (\%) & 3.4 & 5.9 & 3.5 & 11.3 \\
\hline \multicolumn{5}{|l|}{ Tillage } \\
\hline No-tillage & $35.8 \mathrm{a}$ & $23.6 \mathrm{a}$ & $2.5 \mathrm{a}$ & $265.3 \mathrm{a}$ \\
\hline Conventional & $35.3 \mathrm{a}$ & $21.0 \mathrm{~b}$ & $2.4 \mathrm{a}$ & $262.9 \mathrm{a}$ \\
\hline \multirow[t]{2}{*}{$\mathrm{CV}(\%)$} & 7.8 & 3.3 & 2.7 & 12.3 \\
\hline & \multicolumn{4}{|c|}{ Crop 3} \\
\hline Amanda & $35.4 \mathrm{a}$ & $23.8 b$ & $2.46 \mathrm{~b}$ & $281.8 \mathrm{ab}$ \\
\hline Solaris & $35.4 \mathrm{a}$ & $24.3 b$ & $2.5 \mathrm{~b}$ & $280.5 \mathrm{ab}$ \\
\hline Vanda & $33.7 \mathrm{a}$ & $29.6 \mathrm{a}$ & $2.8 \mathrm{a}$ & $312.2 \mathrm{a}$ \\
\hline Vera & $35.2 \mathrm{a}$ & $23.5 \mathrm{~b}$ & $2.4 \mathrm{~b}$ & $259.9 \mathrm{~b}$ \\
\hline CV (\%) & 3.8 & 2.4 & 4.8 & 12.6 \\
\hline \multicolumn{5}{|l|}{ Tillage } \\
\hline No-tillage & $35.8 \mathrm{a}$ & $25.9 \mathrm{a}$ & $2.6 \mathrm{a}$ & $303.1 \mathrm{a}$ \\
\hline Conventional & $34.1 \mathrm{a}$ & $24.7 \mathrm{~b}$ & $2.5 \mathrm{a}$ & $264.1 \mathrm{~b}$ \\
\hline$\overline{\mathrm{CV}(\%)}$ & 6.1 & 5.6 & 5.0 & 8.9 \\
\hline
\end{tabular}

(1)Means followed by equal letters, in the columns, do not differ by Tukey's test, at $5 \%$ probability. $\mathrm{HD}$, head diameter; $\mathrm{NL}$, number of leaves; $\mathrm{SD}$, stem diameter; and FW, fresh weight of shoots. 
of ruzi grass in the first crop, the index SPAD (Soil Plant Analysis Development) related to $\mathrm{N}$ was higher in the no-tillage management. In the second and third crops, there were no differences among treatments (Table 5). Nitrogen fertilizer provided once a week by fertigation probably explains these results. The fertilizer can be a source to supply the immobilization of $\mathrm{N}$. Therefore, it is likely that the physical hindrance for the lettuce establishment provided by ruzi grass roots, associated with a higher-straw amount in the first crop, caused a greater effect on lettuce plants than possible $\mathrm{N}$ immobilization.

There were no differences among cultivars for head diameter. 'Vanda' was the cultivar with the highest number of leaves and greatest stem diameter. Fresh weight was similar among cultivars in the first crop; however, 'Vanda' showed a greater fresh weight than 'Solaris' in the second crop, and 'Vera' in the third crop (Table 4). These results can be attributed to the climatic characteristics, in each planting period that favored one, or other cultivar.

Bed height was initially of $35 \mathrm{~cm}$, and showed a greater reduction in the conventional tillage than in the no-tillage treatment (raised 81 days before the conventional tillage bed) (Table 5). The high rainfall of the summer period (Figure 1) is an important factor for determining the highest-soil loss. Bed conservation can be attributed to ruzi grass roots, as well as to the shoots that reduce the impact of raindrops. According to Salton

Table 5. Soil plant analysis development (SPAD) index and bed height in the cultivation of different crisphead lettuce (Lactuca sativa) cultivars transplanted and managed in notillage, on straw of ruzi grass (Urochloa ruziziensis) or in conventional tillage, in sucessive crops $^{(1)}$.

\begin{tabular}{lcccc}
\hline Cultivar & \multicolumn{3}{c}{ Chlorophyll (SPAD index) } & Bed height (cm) \\
\cline { 2 - 4 } & Crop 1 & Crop 2 & Crop 3 & After crop 3 \\
\hline Amanda & $18.54 \mathrm{a}$ & $16.52 \mathrm{a}$ & $15.60 \mathrm{~b}$ & $15.2 \mathrm{a}$ \\
Solaris & $18.46 \mathrm{a}$ & $16.08 \mathrm{a}$ & $16.16 \mathrm{~b}$ & $16.1 \mathrm{a}$ \\
Vanda & $19.01 \mathrm{a}$ & $17.32 \mathrm{a}$ & $18.12 \mathrm{a}$ & $17.1 \mathrm{a}$ \\
Vera & $18.94 \mathrm{a}$ & $16.88 \mathrm{a}$ & $15.74 \mathrm{~b}$ & $16.9 \mathrm{a}$ \\
\hline CV (\%) & 7.3 & 13.5 & 7.0 & 9.3 \\
\hline Tillage & & & & \\
No-tillage & $19.86 \mathrm{a}$ & $17.09 \mathrm{a}$ & $16.15 \mathrm{a}$ & $18.6 \mathrm{a}$ \\
Conventional & $17.61 \mathrm{~b}$ & $16.31 \mathrm{a}$ & $16.67 \mathrm{a}$ & $14.0 \mathrm{~b}$ \\
\hline CV (\%) & 4.9 & 13.8 & 3.6 & 16.8
\end{tabular}

(1)Means followed by equal letters, in the columns, do not differ by Tukey's test, at $5 \%$ probability.
\& Tomazi (2014), the cultivation of plants that show abundant root systems, such as grasses, contributed to the formation and stability of soil macroaggregates, which resulted in a higher-soil resistance to erosion and compaction. O'Rourke \& Petersen (2016) reported that conventional-till pumpkin plots lost nine times more soil than conservation-tilled treatments.

\section{Conclusions}

1. Ruzi grass [Urochloa ruziziensis (syn. Brachiaria ruziziensis)] used as cover crop for lettuce (Lactuca sativa), in no-tillage, results in soil-temperature decrease up to $3.7^{\circ} \mathrm{C}$, and in weed density reduction of 3.7 times, in comparison with conventional tillage.

2. There are no differences among the lettuce cultivars Amanda, Solaris, Vanda, and Vera for their performance in conventional or no-tillage systems.

3. Lettuce grown in no-tillage on ruzi grass shows more sustainable crop yield and improved conservation of bed structure than lettuce grown in conventional tillage.

\section{Acknowledgments}

To Fundação de Amparo à Pesquisa do Estado de São Paulo (Fapesp), for financial support.

\section{References}

ARAÚJO NETO, S.E. de; GALVÃO, R. de O.; FERREIRA, R.L.F.; PARMEJIANI, R.S.; NEGREIROS, J.R. da S. Plantio direto de cebolinha sobre cobertura vegetal com efeito residual da aplicação de composto orgânico. Ciência Rural, v.40, p.12061209, 2010. DOI: 10.1590/S0103-84782010000500033.

ARGENTA, G.; SILVA, P.R.F. da; FLECK, N.G.; BORTOLINI, C.G.; NEVES, R.; AGOSTINETTO, D. Efeitos do manejo mecânico e químico da aveia-preta no milho em sucessão e no controle do capim-papuã. Pesquisa Agropecuária Brasileira, v.36, p.851-860, 2001. DOI: 10.1590/S0100-204X2001000600002.

BASKIN, C.C.; BASKIN, J.M. The natural history of soil seed banks of arable land. Weed Science, v.54, p.549-557, 2006. DOI: 10.1614/WS-05-034R.1.

BECKIE, H.J.; JOHNSON, E.N.; BLACKSHAW, R.E.; GAN, Y. Weed suppression by canola and mustard cultivars. Weed Technology, v.22, p.182-185, 2008. DOI: 10.1614/WT-07-126.1.

BLANCO-CANQUI, H.; SHAVER, T.M.; LINDQUIST, J.L.; SHAPIRO, C.A.; ELMORE, R.W.; FRANCIS, C.A.; HERGERT, G.W. Cover crops and ecosystem services: insights from studies in temperate soils. Agronomy Journal, v.107, p.2449-2474, 2015. DOI: 10.2134/agronj15.0086. 
CIIAGRO. Centro Integrado de Informações Agrometeorológicas. Monitoramento climatológico: Presidente Prudente. Available at: $\quad<$ http://www.ciiagro.sp.gov.br/ciiagroonline/Listagens/ MonClim/LMClimLocal.asp>. Accessed on: May 152016.

COLQUHOUN, J.B.; KONIECZKA, C.M.; RITTMEYER, R.A. Ability of potato cultivars to tolerate and suppress weeds. Weed Technology, v.23, p.287-291, 2009. DOI: 10.1614/WT-08-062.1.

CONSTANTIN, J.; OLIVEIRA JR., R.S.; CAVALIERI, S.D.; ARANTES, J.G.Z.; ALONSO, D.G.; ROSO, A.C.; COSTA, J.M. Interação entre sistemas de manejo e de controle de plantas daninhas em pós-emergência afetando o desenvolvimento e a produtividade do milho. Planta Daninha, v.25, p.513-520, 2007. DOI: 10.1590/S0100-83582007000300010.

CORRÊA, J.C.; HOFFMANN, H.P.; MONQUERO, P.; CASAGRANDE, J.C.; PUGA, A.P. Efeito do intervalo de dessecação antecedendo a semeadura do milho e do uso de diferentes espécies de plantas de cobertura. Revista Brasileira de Ciência do Solo, v.32, p.739-746, 2008. DOI: 10.1590/S010006832008000200028.

FERREIRA, R.L.F.; ARAÚJO NETO, S.E. de; SILVA, S.S. da; ABUD, E.A.; REZENDE, M.I. de F.L.; KUSDRA, J.F. Combinações entre cultivares, ambientes, preparo e cobertura do solo em características agronômicas de alface. Horticultura Brasileira, v.27, p.383-388, 2009. DOI: 10.1590/S010205362009000300023.

HIRATA, A.C.S.; HIRATA, E.K.; GUIMARÃES, E.C.; RÓS, A.B.; MONQUERO, P.A. Plantio direto de alface-americana sobre plantas de cobertura dessecadas ou roçadas. Bragantia, v.73, p.178-183, 2014. DOI: 10.1590/brag.2014.024.

HORTON, R.; BRISTOW, K.L.; KLUITENBERG, G.J.; SAUER, T.J. Crop residue effects on surface radiation and energy balance - review. Theoretical and Applied Climatology, v.54, p.27-37, 1996. DOI: $10.1007 /$ BF00863556.

FONTES, P.C.R.; NUNES, J.C.S.; FERNANDES, H.C.; ARAÚJO, E.F. Características físicas do solo e produtividade da batata dependendo de sistemas de preparo do solo. Horticultura Brasileira, v.25, p.355-359, 2007. DOI: 10.1590/S010205362007000300007.

JOKELA, D.; NAIR, A. No tillage and strip tillage effects on plant performance, weed suppression, and profitability in transitional organic broccoli production. HortScience, v.51, 1103-1110, 2016. DOI: 10.21273/HORTSCI10706-16.

LAFTA, A.; TURINI, T.; SANDOYA, G.V.; MOU, B. Field evaluation of green and red leaf lettuce genotypes in the Imperial, San Joaquin, and Salinas Valleys of California for heat tolerance and extension of the growing seasons. HortScience, v.52, p.4048, 2017. DOI: 10.21273/HORTSCI10835-16.

MEAGY, MD. J.; EATON, T.E.; BARKER, A.V. Nutrient density in lettuce cultivars grown with organic or conventional fertilization with elevated calcium concentrations. HortScience, v.48, p.1502-1507, 2013.

MINOLTA, C. Manual for chlorophyll meter SPAD-502. Osaka: Minolta Radiometric Instruments Divisions, 1989. 22p.
MURPHY, S.D.; CLEMENTS, D.R.; BELAOUSSOFF, S.; KEVAN, P.G.; SWANTON, C.J. Promotion of weed species diversity and reduction of weed seedbanks with conservation tillage and crop rotation. Weed Science, v.54, p.69-77, 2006. DOI: 10.1614/WS-04-125R1.1.

NEPOMUCENO, M.P.; VARELA, R.M.; ALVES, P.L.C.A.; MARTINS, J.V.F. Períodos de dessecação de Urochloa ruziziensis e seu reflexo na produtividade da soja RR. Planta Daninha, v.30, p.557-565, 2012. DOI: 10.1590/S0100-83582012000300011.

O'ROURKE, M.E.; PETERSEN, J. Reduced tillage impacts on pumpkin yield, weed pressure, soil moisture, and soil erosion. HortScience, v.51, p.1524-1528, 2016. DOI: 10.21273/ HORTSCI11226-16.

OLIVEIRA, M.L.; RUIZ, H.A.; COSTA, L.M.; SCHAEFER, C.E.G.R. Flutuações de temperatura e umidade do solo em resposta à cobertura vegetal. Revista Brasileira de Engenharia Agrícola e Ambiental, v.9, p.535-539, 2005. DOI: 10.1590/S141543662005000400015.

OLIVEIRA, N.G. de; DE-POLLI, H.; ALMEIDA, D.L. de; GUERRA, J.G.M. Plantio direto de alface adubada com cama de aviário sobre coberturas vivas de grama e amendoim forrageiro. Horticultura Brasileira, v.24, p.112-117, 2006. DOI: 10.1590/ S0102-05362006000100023.

PANNACCI, E.; LATTANZI, B.; TEI, F. Non-chemical weed management strategies in minor crops: a review. Crop Protection, v.96, p.44-58, 2017. DOI: 10.1016/j.cropro.2017.01.012.

PEACHEY, R.E.; WILLIAM, R.D.; MALLORY-SMITH, C. Effect of no-till or conventional planting and cover crops residues on weed emergence in vegetable row crop. Weed Technology, v.18, p.1023-1030, 2004. DOI: 10.1614/WT-03-205R.

PIEPER, J.R.; BROWN, R.N.; AMADOR, J.A. Effects of three conservation tillage strategies on yields and soil health in a mixed vegetable production system. HortScience, v.50, p.1770-1776, 2015.

PRICE, A.J.; NORSWORTHY, J.K. Cover crops for weed management in southern reduced-tillage vegetable cropping systems. Weed Technology, v.27, p.212-217, 2013. DOI: 10.1614/ WT-D-12-00056.1.

RAIJ, B. van; ANDRADE, J.C. de; CANTARELLA, H.; QUAGGIO, J.A (Ed.). Análise química para avaliação da fertilidade de solos tropicais. Campinas: IAC, 2001. p.173-199.

RESENDE, G.M. de; YURI, J.E.; SOUZA, R.J. de. Épocas de plantio e doses de silício no rendimento de alface tipo americana. Horticultura Brasileira, v.25, p.455-459, 2007. DOI: 10.1590/ S0102-05362007000300026.

RESENDE, G.M.; YURI, J.E.; COSTA, N.D.; MOTA, J.H. Desempenho de cultivares de cenoura em sistema orgânico de cultivo em condições de temperaturas elevadas. Horticultura Brasileira, v.34, p.121-125, 2016. DOI: 10.1590/S0102053620160000100018.

SALA, F.C; COSTA, C.P. da. Retrospectiva e tendência da alfacicultura brasileira. Horticultura Brasileira, v.30, p.187-194, 2012. DOI: 10.1590/S0102-05362012000200002. 
SALTON, J.C.; TOMAZI, M. Sistema radicular de plantas e qualidade do solo. Dourados: Embrapa Agropecuária Oeste, 2014. 6p. (Comunicado técnico, 198).

SILVA HIRATA, A.C.; HIRATA, E.K.; MONQUERO, P.A.; GOLLA, A.R.; NARITA, N. Plantas de cobertura no controle de plantas daninhas na cultura do tomate em plantio direto. Planta Daninha, v.27, p.465-472, 2009. DOI: 10.1590/S010083582009000300006.

SILVA, F.A.S. Sistema de Assistência Estatística - ASSISTAT: versão 7.6 beta (em linha). Campina Grande: Departamento de Engenharia Agrícola, Universidade Federal de Campina Grande, 2008.

TAVELLA, L.B.; GALVÃO, R. de O.; FERREIRA, R.L.F.; ARAÚJO NETO, S.E. de; NEGREIROS, J.R. da S. Cultivo orgânico de coentro em plantio direto utilizando cobertura viva e morta adubado com composto. Revista Ciência
Agronômica, v.41, p.614-618, 2010. DOI: 10.1590/S180666902010000400014.

TEIXEIRA, C.M.; CARVALHO, G.J. de; ANDRADE, M.J.B. de; SILVA, C.A.; PEREIRA, J.M. Decomposição e liberação de nutrientes das palhadas de milheto e milheto + crotalária no plantio direto do feijoeiro. Acta Scientiarum. Agronomy, v.31, p.647-653, 2009. DOI: 10.4025/actasciagron.v31i4.1356.

TOLEDO-SOUZA, E.D. de; SILVEIRA, P.M. da; LOBO JUNIOR, M.; CAFÉ FILHO, A.C. Sistemas de cultivo, sucessões de culturas, densidade do solo e sobrevivência de patógenos de solo. Pesquisa Agropecuária Brasileira, v.43, p.971-978, 2008. DOI: 10.1590/S0100-204X2008000800004.

TRANI, P.E.; PURQUÉRIO, L.F.V.; FIGUEIREDO, G.J.B.; TIVELLI, S.W.; BLAT, S.F. Calagem e adubação da alface, almeirão, agrião d' água, chicória, coentro, espinafre e rúcula. Campinas: IAC, 2014. 16p (IAC. Informações Tecnológicas, 97).

Received on May 10, 2017 and accepted on October 10, 2017 